\title{
Paenibacillus ginsengarvi sp. nov., isolated from soil from ginseng cultivation
}

\author{
Correspondence \\ Min-Ho Yoon \\ mhyoon@cnu.ac.kr
}

\author{
Min-Ho Yoon, ${ }^{1}$ Leonid N. Ten ${ }^{2}$ and Wan-Taek Im $^{3}$ \\ ${ }^{1}$ Department of Bio-Environmental Chemistry, College of Agriculture and Life Sciences, \\ Chungnam National University, Daejeon 305-764, Republic of Korea \\ ${ }^{2}$ Department of Biology and Medicinal Sciences, Pai Chai University, Daejeon 302-735, \\ Republic of Korea \\ ${ }^{3}$ Department of Biological Sciences, Korea Advanced Institute of Science and Technology, \\ 373-1 Guseong-dong, Yuseong-gu, Daejeon 305-701, Republic of Korea
}

The genus Paenibacillus was defined in 1993 after an extensive comparative analysis of the 16S rRNA gene sequences of 51 species of the genus Bacillus (Ash et al., 1991, 1993). When the genus was first described, it comprised 11 species, including Paenibacillus polymyxa as the type species. Currently, the genus Paenibacillus encompasses over 70 species (Euzéby, 1997; updated January 2007). Members of the genus Paenibacillus are aerobic or facultatively anaerobic organisms with typically Gram-positive cell walls and produce ellipsoidal endospores in swollen sporangia. The DNA G $+\mathrm{C}$ contents range from 39 to $54 \mathrm{~mol} \%$ and anteiso- $\mathrm{C}_{15: 0}$ is the major cellular fatty acid (Shida et al., 1997).

During the course of an investigation of the culturable aerobic and facultatively anaerobic bacterial community in soil from a ginseng field in Pocheon Province, South Korea, a large number of bacteria were isolated. In this study, we have characterized one of these isolates, strain Gsoil $139^{\mathrm{T}}$. Phenotypic, chemotaxonomic and phylogenetic analyses have established the affiliation of this isolate to the genus Paenibacillus, and the data obtained in this work

The GenBank/EMBL/DDBJ accession number for the 16S rRNA gene sequence of strain Gsoil $139^{\top}$ is AB271057.

An extended 16S rRNA gene sequence-based neighbour-joining tree is available as supplementary material with the online version of this paper. suggest that the isolate represents a novel species of this genus.

Strain Gsoil $139^{\mathrm{T}}$ was originally isolated from soil from a ginseng field in Pocheon Province. The soil sample was suspended in $50 \mathrm{mM}$ phosphate buffer $\left(\mathrm{l}^{-1}: 5.355 \mathrm{~g}\right.$ $\mathrm{K}_{2} \mathrm{HPO}_{4}, 2.62 \mathrm{~g} \mathrm{KH}_{2} \mathrm{PO}_{4} ; \mathrm{pH} 7.0$ ) and serial decimal dilutions of the suspension were spread-plated onto modified R2A agar plates containing the following $\left(1^{-1}\right)$ : $0.25 \mathrm{~g}$ tryptone, $0.25 \mathrm{~g}$ peptone, $0.25 \mathrm{~g}$ yeast extract, $0.125 \mathrm{~g}$ malt extract, $0.125 \mathrm{~g}$ beef extract, $0.25 \mathrm{~g}$ Casamino acids, 0.25 g soytone, 0.5 g glucose, 0.3 g soluble starch, $0.2 \mathrm{~g}$ xylan, $0.3 \mathrm{~g}$ sodium pyruvate, $0.3 \mathrm{~g} \mathrm{~K}_{2} \mathrm{HPO}_{4}$, $0.05 \mathrm{~g} \mathrm{MgSO}_{4}, 0.05 \mathrm{~g} \mathrm{CaCl}_{2}$ and $15 \mathrm{~g}$ agar. The plates were then incubated at $30{ }^{\circ} \mathrm{C}$ for 1 month. On the $10^{7}$-diluted plate, 40-50 colonies appeared, of which strain Gsoil $139^{\mathrm{T}}$ was one. Single colonies were purified by transferring them onto new plates (modified R2A medium) and repeated incubation. Strain Gsoil $139^{\mathrm{T}}$ was one of the isolates that appeared on the modified R2A agar plates under aerobic conditions. It was routinely cultured on R2A agar (Difco) at $30{ }^{\circ} \mathrm{C}$ and maintained as a glycerol suspension $(20 \%$, $\mathrm{w} / \mathrm{v})$ at $-70{ }^{\circ} \mathrm{C}$.

For phylogenetic analysis of strain Gsoil $139^{\mathrm{T}}$, DNA was extracted using a genomic DNA extraction kit (Core Biosystems); the 16S rRNA gene was amplified by a PCR and then sequencing of the purified PCR product was 
carried out according to Kim et al. (2005). The complete $16 \mathrm{~S}$ rRNA gene sequence was compiled using SeqMan software (DNASTAR). The 16S rRNA gene sequences of related taxa were obtained from the GenBank database. Multiple alignments were performed by using the CLUSTAL_X program (Thompson et al., 1997). Gaps were edited in the BioEdit program (Hall, 1999). Evolutionary distances were calculated using the Kimura two-parameter model (Kimura, 1983) and phylogenetic trees were constructed by using the neighbour-joining method (Saitou \& Nei, 1987) and the maximum-parsimony method (Fitch, 1971) using the MEGA3 program (Kumar et al., 2004) with bootstrap values based on 1000 replications (Felsenstein, 1985).

Comparative analysis of the 16S rRNA gene sequence of strain Gsoil $139^{\mathrm{T}}$ (1469 bp) showed that this strain is phylogenetically affiliated to Paenibacillus species. The phylogenetic tree (Fig. 1) based on the neighbour-joining algorithm showed that strain Gsoil $139^{\mathrm{T}}$ fell within the radiation of the cluster comprising Paenibacillus species (see the expanded phylogenetic tree; Supplementary Fig. S1 available in IJSEM Online), joining Paenibacillus hodogayensis JCM $12520^{\mathrm{T}}$ with a bootstrap resampling value of $99.0 \%$. The closest phylogenetic neighbours of strain Gsoil $139^{\mathrm{T}}$ are $P$. hodogayensis $\mathrm{SG}^{\mathrm{T}}(95.6 \%)$ and Paenibacillus koleovorans $\mathrm{TB}^{\mathrm{T}}(93.8 \%)$. The $16 \mathrm{~S}$ rRNA gene sequence similarity to type strains of all other Paenibacillus species with validly published names was below $93.8 \%$; according to Wayne et al. (1987), the phylogenetic definition of a species requires strains to show approximately $\geqslant 70 \%$ DNA-DNA relatedness. The available data indicate that organisms having less than $97.0 \% 16 \mathrm{~S}$ rRNA gene sequence similarity will not exhibit more than $60 \%$ reassociation, irrespective of the hybridization method applied (Stackebrandt \& Goebel, 1994; Keswani \& Whitman, 2001). This phylogenetic result demonstrated that strain Gsoil $139^{\mathrm{T}}$ was not related to any previously described Paenibacillus taxa at the species level.

The Gram reaction was performed using the non-staining method, as described by Buck (1982). Cell morphology and motility were observed with a Nikon light microscope ( $\times 1000$ magnification) using the hanging drop technique with cells allowed to grow on R2A agar for 3 days at $30{ }^{\circ} \mathrm{C}$. Catalase and oxidase tests were performed as outlined by Cappuccino \& Sherman (2002). Acid production from 49 carbon sources was tested at $30{ }^{\circ} \mathrm{C}$ with API $50 \mathrm{CH}$ in combination with API $50 \mathrm{CHB} / \mathrm{E}$ medium (bioMérieux), which was used for inoculum preparation, and evaluated after 2 days. Growth at a variety of temperatures $(4,15,18$, $25,30,37,42$ and $45^{\circ} \mathrm{C}$ ) was assessed on R2A agar and at $\mathrm{pH}$ 5.0-10.0 (in increments of $0.5 \mathrm{pH}$ units) was assessed in R2A broth. Some physiological characteristics and the utilization of various substrates as sole carbon sources were determined using API 32GN, API 20NE and API 20E galleries according to the instructions of the manufacturer (bioMérieux). Tests for the degradation of DNA [in which DNase agar (Scharlau) plates were flooded with $1 \mathrm{M} \mathrm{HCl}$, casein, chitin, starch (Atlas, 1993), olive oil (Kouker \& Jaeger, 1987), xylan and cellulose (Ten et al., 2004) were performed and evaluated after 7 days. Salt tolerance was tested on R2A medium supplemented with 1-10\% (w/v) $\mathrm{NaCl}$ after 5 days incubation. Growth on nutrient agar, trypticase soy agar (TSA; Difco) and MacConkey agar was also evaluated at $30{ }^{\circ} \mathrm{C}$.

Cells of strain Gsoil $139^{\mathrm{T}}$ were Gram-positive, non-motile rods, $0.3-0.5 \mu \mathrm{m}$ in diameter and $1.5-3.0 \mu \mathrm{m}$ long after 2 days culture on R2A agar. They formed oval spores positioned centrally in swollen sporangia. Colonies grown on R2A agar plates for 2 days were $0.5-1.5 \mathrm{~mm}$ in diameter, circular, convex, non-glossy and white. On R2A agar, the optimum temperature for growth was $37{ }^{\circ} \mathrm{C}$. Strain Gsoil $139^{\mathrm{T}}$ showed oxidase and catalase activities and hydrolysed DNA weakly. Physiological characteristics that can be used to differentiate strain Gsoil $139^{\mathrm{T}}$ from its closest phylogenetic relatives $(P$. hodogayensis and P. koleovorans) are listed in Table 1.

To determine the $\mathrm{G}+\mathrm{C}$ content of the chromosomal DNA, the genomic DNA of the strain was extracted and purified as described by Moore \& Dowhan (1995) and degraded enzymically into nucleosides; the DNA G $+\mathrm{C}$ content was

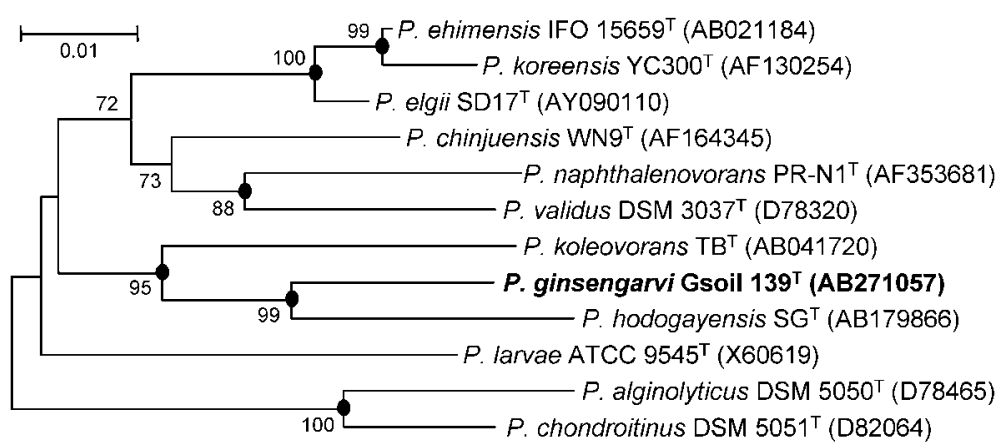

Fig. 1. Phylogenetic tree based on comparative analysis of the $16 \mathrm{~S}$ rRNA gene sequences of strain Gsoil $139^{\top}$ and phylogenetically related species of the genus Paenibacillus constructed using the neighbour-joining method. Bootstrap percentages (from 1000 replications) greater than $70 \%$ are shown at branch points. Filled circles indicate that the corresponding nodes were also recovered in the tree generated with the maximum-parsimony algorithm. Bar, 0.01 substitutions per nucleotide position. An extended version of this tree is available as Supplementary Fig. S1 in IJSEM Online. 
Table 1. Phenotypic characteristics of strain Gsoil $139^{\top}$ and type strains of phylogenetically related Paenibacillus species

Strains: 1 , Gsoil $139^{\mathrm{T}} ; 2$, P. hodogayensis JCM $12520^{\mathrm{T}}$ (data from Takeda et al., 2005); 3, P. koleovorans JCM $11186^{\mathrm{T}}$ (Takeda et al., 2002). All of the strains are negative for arginine dihydrolase, lysine decarboxylase, ornithine decarboxylase, urease, gelatin hydrolysis, indole production and citrate utilization. None of the strains produces acid from D-fructose, D-fucose, L-fucose, D-galactose, Dlyxose, D-mannose, L-rhamnose, L-sorbose, D-tagatose, L-xylose, adonitol, D-arabitol, L-arabitol, dulcitol, erythritol, inositol, Dsorbitol, xylitol, inulin, $\beta$-gentiobiose, D-melezitose, gluconate, starch or glycogen. + , Positive; - , negative; $\mathrm{W}$, weakly positive.

\begin{tabular}{|lccc|}
\hline Characteristic & $\mathbf{1}$ & $\mathbf{2}$ & $\mathbf{3}$ \\
\hline Anaerobic growth & - & - & + \\
Optimum growth temperature $\left({ }^{\circ} \mathrm{C}\right)$ & 37 & 30 & 30 \\
Catalase activity & + & + & - \\
Oxidase activity & + & + & - \\
Voges-Proskauer test & + & - & - \\
Acid production from: & & & \\
Amygdalin & + & W & - \\
L-Arabinose & + & - & - \\
Arbutin & + & - & - \\
D-Glucose & + & + & - \\
Glycerol & + & + & - \\
D-Lactose & - & W & - \\
D-Mannitol & - & + & - \\
D-Melibiose & + & + & - \\
Methyl $\alpha$-D-glucoside & + & W & - \\
D-Raffinose & + & - & - \\
D-Ribose & + & W & - \\
Salicin & - & W & - \\
Sucrose & + & + & - \\
D-Xylose & + & - & - \\
DNA G + C content $($ mol\%) & 48.1 & 55.0 & $54.0-55.8$ \\
& & & \\
\hline
\end{tabular}

then determined as described by Mesbah et al. (1989) using reversed-phase HPLC. Isoprenoid quinones were extracted with chloroform/methanol $(2: 1, \mathrm{v} / \mathrm{v})$, evaporated under vacuum conditions and re-extracted in $\mathrm{n}$-hexane/water $(1: 1, \mathrm{v} / \mathrm{v})$. The crude quinone in $\mathrm{n}$-hexane was purified using silica Sep-Pak Vac cartridges (Waters) and subsequently analysed by HPLC, as described previously (Hiraishi et al., 1996). Cellular fatty acid profiles were determined for strains grown on TSA for 3 days at $30{ }^{\circ} \mathrm{C}$. The cellular fatty acids were saponified, methylated and extracted according to the protocol of the Sherlock Microbial Identification System (MIDI). The fatty acids were then analysed by gas chromatography (6890; Hewlett Packard) using the Microbial Identification software package (Sasser, 1990). Duplicate experiments were performed.

The DNA G $+\mathrm{C}$ content of strain Gsoil $139^{\mathrm{T}}$ was $48.1 \mathrm{~mol} \%$, which lies within the range observed for members of the genus Paenibacillus. The respiratory quinone system present in Gsoil $139^{\mathrm{T}}$ supports its affiliation with the genus Paenibacillus, in which most species have MK-7 as the major quinone (Shida et al., 1997). The fatty acids found in isolate Gsoil $139^{\mathrm{T}}$ are shown in Table 2 and are compared with values available for phylogenetically related Paenibacillus strains. Anteisobranched $\mathrm{C}_{15: 0}$, the major fatty acid present in members of the genus Paenibacillus (Shida et al., 1997), was also the major fatty acid component of strain Gsoil $139^{\mathrm{T}}$, comprising $27.9 \%$ of the total. However, some qualitative and quantitative differences in fatty acid content could be observed between strain Gsoil $139^{\mathrm{T}}$ and the phylogenetically closest relatives. The next most predominant fatty acid found in strain Gsoil $139^{\mathrm{T}}$ was iso- $\mathrm{C}_{16: 0}$, comprising $26.8 \%$. This value is much higher than those reported for the reference species (Table 2).

All of the characteristics determined for strain Gsoil $139^{\mathrm{T}}$ are in accordance with those for the genus Paenibacillus. On the basis of the phylogenetic distance from established Paenibacillus species, indicated by the relatively low $16 \mathrm{~S}$ rRNA gene sequence similarities $(<96 \%)$, and the specific combination of phenotypic characteristics, it is demonstrable that Gsoil $139^{\mathrm{T}}$ is not affiliated to any species of this genus. Therefore, on the basis of the data presented, strain Gsoil $139^{\mathrm{T}}$ should be placed in the genus Paenibacillus within a novel species, for which the name Paenibacillus ginsengarvi sp. nov. is proposed.

\section{Description of Paenibacillus ginsengarvi sp. nov.}

Paenibacillus ginsengarvi (gin.seng.ar'vi. N.L. n. ginsengum ginseng; L. n. arvum a field; N.L. gen. n. ginsengarvi of a ginseng field, the source of the type strain).

Table 2. Cellular fatty acid profile of strain Gsoil $139^{\top}$ and type strains of phylogenetically related species of the genus Paenibacillus

Strains: 1, Gsoil $139^{\mathrm{T}}$; 2, P. hodogayensis JCM $12520^{\mathrm{T}}$ (data from Takeda et al., 2005); 3, P. koleovorans JCM $11186^{\mathrm{T}}$ (Takeda et al., 2002). NR, not reported.

\begin{tabular}{|lccl|}
\hline Fatty acid & $\mathbf{1}$ & $\mathbf{2}$ & $\mathbf{3}$ \\
\hline Straight-chain saturated & & & \\
$\mathrm{C}_{14: 0}$ & 0.7 & $\mathrm{NR}$ & $\mathrm{NR}$ \\
$\mathrm{C}_{15: 0}$ & 3.4 & 19.2 & 13.3 \\
$\mathrm{C}_{16: 0}$ & 3.2 & 7.6 & 22.8 \\
$\mathrm{C}_{17: 0}$ & 0.3 & $\mathrm{NR}$ & $\mathrm{NR}$ \\
Branched saturated & & & \\
iso- $\mathrm{C}_{14: 0}$ & 10.0 & $\mathrm{NR}$ & $\mathrm{NR}$ \\
iso- $\mathrm{C}_{15: 0}$ & 21.9 & $\mathrm{NR}$ & $\mathrm{NR}$ \\
iso-- $16: 0$ & 26.8 & 9.6 & $\mathrm{NR}$ \\
iso- $\mathrm{C}_{17: 0}$ & 4.0 & $\mathrm{NR}$ & $\mathrm{NR}$ \\
anteiso-C & & 39.7 & 37.4 \\
anteiso- $\mathrm{C}_{17: 0}$ & 27.9 & 39.7 & $\mathrm{NR}$ \\
\hline
\end{tabular}


Cells are Gram-positive, non-motile rods that form oval spores positioned centrally in swollen sporangia. Oxidase and catalase reactions are positive. Nitrate is not reduced to nitrite. Anaerobic growth does not occur. Grows between 18 and $45{ }^{\circ} \mathrm{C}$ (optimum $37{ }^{\circ} \mathrm{C}$ ) and at $\mathrm{pH} 5.0-8.5$ (optimum $\mathrm{pH} 6.5-7.0)$. Tolerates $\mathrm{NaCl}$ at $2 \%(\mathrm{w} / \mathrm{v})$ but not $3 \%$. Growth occurs on TSA and nutrient agar but not on MacConkey agar. Hydrolyses DNA weakly, but does not hydrolyse chitin, starch, cellulose, xylan, lipids or casein. Positive for $\beta$-glucosidase and $\beta$-galactosidase. The following substrates are utilized for growth: D-glucose, maltose, D-melibiose, D-ribose, sucrose, salicin and gluconate. The following substrates are not utilized for growth: Dmannose, L-fucose, L-rhamnose, L-arabinose, propionate, caprate, phenylacetate, 3-hydroxybenzoate, 4-hydroxybenzoate, malonate, acetate, 3-hydroxybutylate, valerate, citrate, lactate, malate, 5-ketogluconate, 2-ketoglutarate, itaconate, adipate, suberate, D-sorbitol, D-mannitol, inositol, glycogen, $N$-acetyl-D-glucosamine, gelatin, urea, nitrate, L-serine, L-tryptophan, L-alanine, L-arginine, Lhistidine and L-proline. Positive for $\beta$-galactosidase and the Voges-Proskauer test in API 20E tests. Arginine dihydrolase, lysine decarboxylase, ornithine decarboxylase, tryptophan deaminase, urease, gelatin hydrolysis, indole and hydrogen sulphide production are negative. Acids are produced from glycerol, D-arabinose, L-arabinose, D-ribose, D-xylose, methyl $\beta$-D-xyloside, D-glucose, methyl $\alpha$-Dglucoside, amygdalin, arbutin, D-cellobiose, maltose, Dmelibiose, sucrose, trehalose, D-raffinose and D-turanose. Acids are not produced from erythritol, L-xylose, adonitol, D-galactose, D-fructose, D-mannose, L-sorbose, L-rhamnose, dulcitol, inositol, D-mannitol, D-sorbitol, methyl $\alpha$-Dmannoside, $N$-acetyl-D-glucosamine, salicin, D-lactose, inulin, D-melezitose, starch, glycogen, xylitol, $\beta$-gentiobiose, D-lyxose, D-tagatose, D-fucose, L-fucose, D-arabitol, L-arabitol, gluconate, 2-ketogluconate or 5-ketogluconate. MK-7 is the predominant menaquinone. The major fatty acids are anteiso- $\mathrm{C}_{15: 0}$, iso- $\mathrm{C}_{16: 0}$ and iso- $\mathrm{C}_{15: 0}$. The $\mathrm{G}+\mathrm{C}$ content of the genomic DNA of the type strain is $48.1 \mathrm{~mol} \%$.

The type strain, Gsoil $139^{\mathrm{T}}\left(=\right.$ KCTC $13059^{\mathrm{T}}=\mathrm{DSM}$ $\left.18677^{\mathrm{T}}\right)$, was isolated from soil from a ginseng field in Pocheon Province, South Korea.

\section{Acknowledgements}

This work was supported by the 2006 Agricultural R\&D Promotion Center Program, Ministry of Agriculture and Forestry, Republic of Korea. We thank Jean Euzéby for his help with the etymology of the species epithet.

\section{References}

Ash, C., Farrow, J. A. E., Wallbanks, S. \& Collins, M. D. (1991). Phylogenetic heterogeneity of the genus Bacillus revealed by comparative analysis of small-subunit-ribosomal RNA sequences. Lett Appl Microbiol 13, 202-206.
Ash, C., Priest, F. G. \& Collins, M. D. (1993). Molecular identification of rRNA group 3 bacilli (Ash, Farrow, Wallbanks and Collins) using a PCR probe test. Proposal for the creation of a new genus Paenibacillus. Antonie van Leeuwenhoek 64, 253-260.

Atlas, R. M. (1993). Handbook of Microbiological Media. Edited by L. C. Parks. Boca Raton, FL: CRC Press.

Buck, J. D. (1982). Nonstaining (KOH) method for determination of Gram reactions of marine bacteria. Appl Environ Microbiol 44, 992-993.

Cappuccino, J. G. \& Sherman, N. (2002). Microbiology: a Laboratory Manual, 6th edn. San Francisco: Pearson Education, Inc. and Benjamin Cummings.

Euzéby, J. P. (1997). List of bacterial names with standing in nomenclature: a folder available on the Internet. Int J Syst Bacteriol 47, 590-592.

Felsenstein, J. (1985). Confidence limits on phylogenies: an approach using the bootstrap. Evolution 39, 783-791.

Fitch, W. M. (1971). Toward defining the course of evolution: minimum change for a specific tree topology. Syst Zool 20, 406-416.

Hall, T. A. (1999). BioEdit: a user-friendly biological sequence alignment editor and analysis program for Windows 95/98/NT. Nucleic Acids Symp Ser 41, 95-98.

Hiraishi, A., Ueda, Y., Ishihara, J. \& Mori, T. (1996). Comparative lipoquinone analysis of influent sewage and activated sludge by highperformance liquid chromatography and photodiode array detection. J Gen Appl Microbiol 42, 457-469.

Keswani, J. \& Whitman, W. B. (2001). Relationship of $16 \mathrm{~S}$ rRNA sequence similarity to DNA hybridization in prokaryotes. Int J Syst Evol Microbiol 51, 667-678.

Kim, M. K., Im, W.-T., Ohta, H., Lee, M. \& Lee, S.-T. (2005). Sphingopyxis granuli sp. nov., a $\beta$-glucosidase-producing bacterium in the family Sphingomonadaceae in $\alpha-4$ subclass of the Proteobacteria. J Microbiol 43, 152-157.

Kimura, M. (1983). The Neutral Theory of Molecular Evolution. Cambridge: Cambridge University Press.

Kouker, G. \& Jaeger, K.-E. (1987). Specific and sensitive plate assay for bacterial lipases. Appl Environ Microbiol 53, 211-213.

Kumar, S., Tamura, K. \& Nei, M. (2004). MEGA3: integrated software for molecular evolutionary genetics analysis and sequence alignment. Brief Bioinform 5, 150-163.

Mesbah, M., Premachandran, U. \& Whitman, W. B. (1989). Precise measurement of the $\mathrm{G}+\mathrm{C}$ content of deoxyribonucleic acid by highperformance liquid chromatography. Int J Syst Bacteriol 39, 159-167.

Moore, D. D. \& Dowhan, D. (1995). Preparation and analysis of DNA: introduction. In Current Protocols in Molecular Biology, pp. 2.0.12.0.3. Edited by F. W. Ausubel, R. Brent, R. E. Kingston, D. D. Moore, J. G. Seidman, J. A. Smith \& K. Struhl. New York: Wiley.

Saitou, N. \& Nei, M. (1987). The neighbor-joining method: a new method for reconstructing phylogenetic trees. Mol Biol Evol 4, 406-425.

Sasser, M. (1990). Identification of bacteria by gas chromatography of cellular fatty acids, MIDI Technical Note 101. Newark, DE: MIDI Inc.

Shida, O., Takagi, H., Kadowaki, K., Nakamura, L. K. \& Komagata, K. (1997). Transfer of Bacillus alginolyticus, Bacillus chondroitinus, Bacillus curdlanolyticus, Bacillus glucanolyticus, Bacillus kobensis, and Bacillus thiaminolyticus to the genus Paenibacillus and emended description of the genus. Int J Syst Bacteriol 47, 289-298.

Stackebrandt, E. \& Goebel, B. M. (1994). Taxonomic note: a place for DNA-DNA reassociation and $16 \mathrm{~S}$ rRNA sequence analysis in the present species definition in bacteriology. Int J Syst Bacteriol 44, 846-849. 
Takeda, M., Kamagata, Y., Shinmaru, S., Nishiyama, T. \& Koizumi, J. (2002). Paenibacillus koleovorans sp. nov., able to grow on the sheath of Sphaerotilus natans. Int J Syst Evol Microbiol 52, 1597-1601.

Takeda, M., Suzuki, I. \& Koizumi, J. (2005). Paenibacillus hodogayensis sp. nov., capable of degrading the polysaccharide produced by Sphaerotilus natans. Int J Syst Evol Microbiol 55, 737-741.

Ten, L. N., Im, W.-T., Kim, M.-K., Kang, M.-S. \& Lee, S.-T. (2004). Development of a plate technique for screening of polysaccharidedegrading microorganisms by using a mixture of insoluble chromogenic substrates. J Microbiol Methods 56, 375-382.
Thompson, J. D., Gibson, T. J., Plewniak, F., Jeanmougin, F. \& Higgins, D. G. (1997). The CLUSTAL_X windows interface: flexible strategies for multiple sequence alignment aided by quality analysis tools. Nucleic Acids Res 25, 4876-4882.

Wayne, L. G., Brenner, D. J., Colwell, R. R., Grimont, P. A. D., Kandler, O., Krichevsky, M. I., Moore, L. H., Moore, W. E. C., Murray, R. G. E. \& other authors (1987). International Committee on Systematic Bacteriology. Report of the ad hoc committee on reconciliation of approaches to bacterial systematics. Int J Syst Bacteriol 37, 463-464. 